\title{
EFEKTIVITAS MODEL PEMBELAJARAN INQUIRY TERHADAP KEMAMPUAN BERPIKIR KREATIF SISWA PADA MATERI TEOREMA PYTHAGORAS
}

\author{
Nelpita Ulandari ${ }^{1}$, Rahmi Putri $^{2}$, Febria Ningsih $^{3}$, Aan Putra $^{4}$ \\ 1,2,3,4 Institut Agama Islam Negeri Kerinci, Jambi,Indonesia \\ nelpitaulandari151@gmail.com
}

\begin{abstract}
By the theory, the inquiry learning model can improve the students' mathematical creative thinking skills due to the students learn by themselves intensively, involved in the learning process directly and they can find and investigate any problems logically and systematically. This study aims to find out the inquiry learning process in the Pythagorean Theorem topic and its effectiveness to increase the sudents' mathematical creative thinking skills. This research used the mixed method with sequential exploratory model. The population of this research is the VIII students of the state islamic junior high school (MTsN) 6 Kerinci. The VIII C and the VIII A of MTsN 6 Kerinci were selected as the experimental and the control group through random sampling technique. The data of learning process was obtained through observation and the data of students' mathematical creative thinking skills was obtained through the tests of mathematical creative thinking skills. The results of data analysis concluded that the inquiry learning model was effective to improve the students' mathematical creative thinking skills.
\end{abstract}

Keywords: inquiry learning model, mixed method, sequential exploratory, mathematical creative thinking

\begin{abstract}
Abstrak
Secara teori model pembelajaran inquiry dapat meningkatkan kemampuan berpikir kreatif siswa dalam pembelajaran matematika dikarenakan siswa lebih banyak belajar sendiri, terlibat secara langsung dalam proses pembelajaran serta dapat menemukan dan menyelidiki permasalahan secara logis dan sistematis. Tujuan penelitian ini adalah untuk mengetahui proses pembelajaran inquiry pada materi Teorema Pythagoras dan efektivitasnya terhadap kemampuan berpikir kreatif siswa. Penelitian ini menggunakan metode campuran (mixed method) model sequential exploratory dengan populasi siswa kelas VIII MTsN 6 Kerinci. Sampel penelitian ini adalah kelas VIII C sebagai kelas eksperimen dan kelas VIII A sebagai kelas kontrol yang dipilih melalui teknik random sampling. Data proses pembelajaran diperoleh melalui observasi sedangkan data kemampuan berpikir kreatif siswa diperoleh melalui tes kemampuan berpikir kreatif. Hasil analisis data menunjukkan bahwa bahwa model pembelajaran inquiry efektif terhadap peningkatan kemampuan berpikir kreatif siswa.
\end{abstract}

Kata kunci: model pembelajaran inquiry, mixed method, sequential exploratory, kemampuan berpikir kreatif

Matematika merupakan suatu ilmu pengetahuan yang dapat melatih berpikir seseorang secara logis, kritis dan kreatif (Mufidah, L., Effendi, D., \& Purwanti, T. T., 2013). Konsep-konsep yang ada di dalam matematika memiliki hubungan yang kuat dan jelas antar konsep sehingga memberikan kemungkinan bagi siapapun yang mempelajarinya bisa berpikir secara rasional. Pada pembelajaran matematika, kemampuan berpikir kreatif siswa sangat penting. Hal ini dikarenakan bahwa kemampuan berpikir kreatif siswa sangat mempengaruhi dalam pencapaian atau keberhasilan siswa dalam pembelajaran. Proses yang dilakukan oleh seseorang untuk memperoleh alternatif jawaban melalui mengembangkan suatu persoalan atau masalah merupakan definisi kemampuan berpikir kreatif (Fadilah, A., 2016). Dengan kata lain berpikir kreatif adalah aktivitas mental yang mempertimbangkan informasi baru dengan pemikiran terbuka yang berhubungan dengan kepekaan 
terhadap masalah, serta dapat menghubungkan ide-ide dalam menyelesaikan masalah (Desi, N., Gembong, S., \& Andari, T., 2013).

Kemampuan berpikir kreatif memiliki arti sebagai kegiatan untuk menghasilkan suatu ide atau gagasan dalam memecahkan masalah, dan saling menghubungkan satu hal dengan hal lainnya untuk menemukan makna (Marliani, N., 2015). Kemampuan berpikir kreatif adalah kemampuan berpikir yang dibiasakan dan dilatih untuk menghidupkan imajinasi, mengungkapkan kemungkinankemungkinan baru dengan membuka sudut pandang yang luas untuk menemukan ide-ide yang baru (Suripah, S., \& Sthephani, A. dalam Johnson, 2017).

Kemampuan berpikir kreatif merupakan kemampuan yang dapat menghasilkan atau mengembangkan sesuatu yang baru dengan kata lain sesuatu yang berbeda dari ide-ide yang telah dihasilkan oleh kebanyakan orang. Kemampuan berpikir kreatif juga merupakan bentuk pemikiran yang mengarahkan kepada wawasan baru, pendekatan baru, atau cara baru dalam memahami sesuatu (Marliani, N., 2015). Kemampuan berpikir kreatif yang tinggi dapat membantu siswa dalam menguasai pembelajaran matematika serta dapat menciptakan atau menemukan cara-cara yang baru dalam menyelesaikan permasalahan yang ada. Dapat disimpulkan bahwa kemampuan berpikir kreatif adalah kemampuan untuk menciptakan sesuatu yang baru yang berbeda dari yang lain, memecahkan masalah, dan menciptakan solusi serta membuat rencana inovatif dengan mempertimbangkan masalah yang kemungkinan akan timbul dan bagaimana cara mengatasinya sehingga dalam pelaksanaannya dilakukan secara matang.

Indikator kemampuan berpikir kreatif siswa ada tiga. Pertama, fluency (kelancaran) yang mengacu pada kebenaran dan kelancaran jawaban yang diberikan siswa. Kedua, flexibility (keragaman) yang mengacu pada cara-cara yang berbeda dan beragam yang diberikan siswa dalam memecahkan dan menyelesaikan masalah. Ketiga, originality (cara baru) mengacu pada cara yang baru atau cara yang muncul dari diri siswa sendiri dan hanya dimiliki oleh siswa yang dituangkan dalam menyelesaikan masalah (Lestari, K. E., \& Yudhanegara, M. R., 2015).

Pada proses pembelajaran matematika, siswa harus dibimbing dan dibiasakan untuk melakukan aktivitas dalam mencari dan memperoleh pemahaman serta dapat mengembangkan pemahaman yang dimilikinya sehingga siswa tidak selalu menunggu pemberian dari guru saja. Pembelajaran yang berpusat pada siswa tentunya akan memberikan kesempatan siswa untuk mencari pengetahuan dan solusi dalam memecahkan suatu permasalahan yang dapat meningkatkan kemampuan berpikir kreatif siswa.

Kenyataan yang terjadi di lapangan kemampuan berpikir kreatif siswa masih kurang terutama pada pembelajaran matematika. Hal ini berdasarkan hasil pengamatan peneliti terhadap proses pembelajaran yang dilakukan di Madrasah Tsanawiyah Negeri (MTsN) 6 Kerinci menunjukkan bahwa proses pembelajaran yang dilakukan masih berpusat kepada guru yang mengakibatkan kemampuan berpikir kreatif siswa masih kurang. Dari cara siswa menyelesaikan tugas yang diberikan oleh guru, siswa hanya bisa mengerjakan soal yang bentuknya persis sama seperti yang dicontohkan 
oleh guru saja. Apabila guru memberikan soal dalam bentuk yang berbeda, hanya satu atau dua orang yang bisa mengerjakannya.

Permasalahan yang terjadi bukan semata-mata disebabkan oleh faktor individu siswa saja, tetapi juga tidak terlepas dari peran guru dalam proses pembelajaran. Setiap kegiatan pembelajaran hendaknya guru melibatkan seluruh siswa sehingga siswa dapat berpartisipasi dalam pembahasan materi yang dibahas. Selain siswa dapat berpartisipasi dan berperan aktif, siswa juga dapat dilatih dalam bernalar, menganalisa, dan mengembangkan kemampuan berpikir kreatif dalam memecahkan suatu masalah (Khomsiatun, S., \& Retnawati, H., 2015). Siswa yang dilatih, dibimbing dan dibiasakan untuk menyelesaikan masalah dalam pembelajaran matematika akan berkembang kemampuan daya pikirnya (Wulansari, T., Putra, A., Rusliah, N., \& Habibi, M., 2019), dan berkembang pula keterampilan siswa dalam menyelesaikan berbagai masalah dalam kehidupan sehari-hari.

Untuk meningkatkan kemampuan berpikir kreatif siswa dalam pembelajaran matematika diperlukan model pembelajaran yang efektif yang dapat melibatkan siswa dalam proses pembelajaran. Model pembelajaran adalah cara yang digunakan guru dalam melaksanakan pembelajaran agar materi yang disampaikan bisa diterima dengan baik oleh siswa (Faturrohman, M., 2015). Model pembelajaran yang digunakan harus bisa mempertimbangkan keberhasilan atau pencapaian dalam meningkatkan kemampuan berpikir kreatif siswa pada pembelajaran matematika.

Salah satu model pembelajaran yang dapat digunakan agar bisa meningkatkan kemampuan berpikir kreatif siswa dalam belajar matematika adalah model pembelajaran inquiry. Model pembelajaran inquiry juga merupakan serangkaian aktivitas belajar mengajar yang melibatkan seluruh kemampuan yang dimiliki siswa untuk mencari dan menyelidiki sehingga mereka dapat merumuskan sendiri penemuannya ( Mashuri, I., 2012). Model pembelajaran inquiry ialah proses membentuk pertanyaan, menyelidiki, dan menciptakan pengetahuan dan hal-hal yang baru yang melibatkan siswa secara penuh dalam pembelajaran (Yumiati, \& Noviyanti, M., 2017).

Selain itu, model pembelajaran inquiry dapat membuat siswa menemukan dan menggunakan bermacam-macam informasi dan ide untuk meningkatkan pengetahuannya terhadap suatu masalah atau persoalan (Widiastuti, \& Santosa, R. H., 2014). Dengan kata lain, model pembelajaran inquiry merupakan model pembelajaran yang melibatkan siswa secara penuh dalam proses pembelajaran, dapat menyelidiki permasalahan yang ada dan menemukan sendiri solusi dari masalah tersebut.

Adapun langkah-langkah model pembelajaran inquiry adalah mengamati, merumuskan masalah, merumuskan hipotesis atau dugaan awal, mengumpulkan data atau informasi yang dibutuhkan dalam menyelesaikan masalah, menguji atau mencari kebenaran dugaan awal dengan mengolah informasi atau data yang ada, dan menarik kesimpulan (Majid, A., 2014). Langkah-langkah pembelajaran inquiry berkaitan dengan pembelajaran penemuan terbimbing yang juga memfasilitasi siswa dalam merumuskan masalah, memberikan dugaan, mengumpulkan data atau informasi yang dibutuhkan, mengolah data untuk membuktikan kebenaran dugaan yang telah dibuat sebelumnya dan menyampaikan gagasan dalam membuat kesimpulan (Putra, A., Syarifuddin, H., \& Zulfah, 2018). 
Pada langkah-langkah model pembelajaran inquiry siswa terlebih dahulu diminta untuk mengamati permasalahan yang diberikan. Selain itu, pada proses pembelajaran yang menggunakan model pembelajaran inquiry, guru tidak hanya mempersiapkan materi pembelajaran yang harus dikuasai melainkan merancang proses pembelajaran yang baik yang bisa membuat siswa menemukan materi yang harus dipahami. Pada proses pembelajaran inquiry, siswa akan dihadapkan dengan suatu masalah yang harus dipecahkan dan diselesaikan secara kelompok. Dengan demikian, akan tercipta suasana belajar yang membuat siswa berperan aktif dalam proses pembelajaran. Pembelajaran tidak hanya menuntut siswa untuk menguasai materi atau pengetahuan saja, tetapi lebih menuntut hubungan tentang apa yang dipelajari siswa yang dapat berguna dalam kehidupannya.

Berdasarkan penjelasan yang telah di uraikan, peneliti akan melakukan penelitian yang bertujuan untuk melihat proses pembelajaran inquiry pada materi Teorema Pythagoras serta efektivitas model pembelajaran inquiry terhadap kemampuan berpikir kreatif siswa pada pembelajaran matematika.

\section{METODE}

Jenis penelitian adalah mixed method. Penelitian mixed method merupakan metode penelitian yang menggabungkan metode kualitatif dan kuantitatif agar memperoleh data yang lebih valid atau teruji kebenarannya. Dalam penelitian ini menggunakan metode mixed method model sequential exploratory. Metode mixed method model sequential exploratory adalah metode penelitian kombinasi yang menggabungkan dua metode yaitu metode penelitian kualitatif dan kuantitatif secara berurutan, di mana pada tahap pertama penelitian menggunakan metode kualitatif dan pada tahap kedua menggunakan metode kuantitatif (Sugiyono, 2014).

Penelitian ini dilakukan di dua kelas yaitu kelas eksperimen yang menggunakan model pembelajaran inquiry dan kelas kontrol yang menggunakan model pembelajaran konvensional. Adapun rancangan penelitian yang dilakukan sebagai berikut.

\section{Tabel 1.}

Rancangan Penelitian

\begin{tabular}{ccc}
\hline Kelas & Perlakuan & Postest \\
\hline Eksperimen & $\mathrm{X}$ & $\mathrm{T}$ \\
Kontrol & & $\mathrm{T}$ \\
\hline
\end{tabular}

Keterangan:

X: Perlakukan pada kelas eksperimen

T: Tes akhir di kelas eksperimen dan kelas kontrol

Penelitian ini dilakukan di Madrasah Tsanawiyah Negeri (MTsN) 6 Kerinci dengan populasi sebagai berikut. 
Tabel 2.

Populasi Penelitian

\begin{tabular}{ccc}
\hline No. & Kelas & Jumlah Siswa \\
\hline 1. & VIII A & 22 Orang \\
\hline 2. & VIII B & 21 Orang \\
\hline 3. & VIII C & 22 Orang \\
\hline 4. & VIII D & 22 Orang \\
\hline & Jumlah Seluruh Siswa & 87 Orang \\
\hline
\end{tabular}

Populasi penelitian sebanyak 87 siswa. Adapun langkah-langkah yang dilakukan penulis dalam menentukan sampel adalah sebagai berikut.

a. Mengumpulkan nilai ulangan harian siswa pada pokok bahasan sebelumnya.

b. Melakukan uji normalitas dengan menggunakan uji Liliefors dengan hasil kelas VIII A $\mathrm{L}_{0}=\mathrm{L}_{\mathrm{t}}=$ 0,1832, kelas VIII B $\mathrm{L}_{0}=0,1088$ dan $\mathrm{L}_{\mathrm{t}}=0,1866$, kelas VIII C $\mathrm{L}_{0}=0,1314$ dan $\mathrm{L}_{\mathrm{t}}=0,1832$, dan kelas VIII D $\mathrm{L}_{0}=0,1488$ dan $\mathrm{L}_{\mathrm{t}}=0,1832$. Semua kelas berdistribusi normal karena $\mathrm{L}_{0}<\mathrm{L}_{\mathrm{t}}$.

c. Melakukan uji homogenitas dengan menggunakan uji Bartlett. Setelah perhitungan uji homogenitas dengan hasil $\mathrm{X}_{\text {hitung }}^{2}=2,323$ dan $\mathrm{X}_{\text {tabel }}^{2}=7,81$ maka $\mathrm{X}_{\text {hitung }}^{2}<\mathrm{X}_{\text {tabel }}^{2}$ sehingga dapat disimpulkan bahwa keempat kelas mempunyai varians homogen pada tingkat kepercayaan $95 \%$.

d. Melakukan uji kesamaan rata-rata (ANOVA) dengan hasil perhitungan $\mathrm{F}_{\text {hitung }}=0,52$ dan $\mathrm{F}_{\text {tabel }}=$ 2,717. Karena $F_{\text {hitung }}<F_{\text {tabel }}$ maka tidak terdapat perbedaan rata-rata nilai ulangan harian siswa.

e. Karena keempat kelas memiliki rata-rata yang sama maka dilakukan random sampling. Dari pengundian tersebut didapatkan kelas VIII C sebagai kelas eksperimen dengan jumlah siswa 22 orang dan kelas VIII A sebagai kelas kontrol dengan jumlah siswa 22 orang.

Setelah melakukan langkah-langkah dalam menentukan sampel diperoleh lah kelas VIII C sebagai kelas eksperimen dan kelas VIII A sebagai kelas kontrol. Instrumen penelitian adalah soal tes. Pengumpulan data dilakukan dengan melakukan observasi dan tes. Pengujian hipotesis penelitian menggunakan teknik analisis variansi satu jalur (uji-t) dengan terlebih dahulu melakukan uji normalitas dengan menggunakan uji Liliefors dan uji homogenitas dengan menggunakan uji Bartlett.

\section{HASIL DAN PEMBAHASAN}

Data tentang kemampuan berpikir kreatif siswa dapat diketahui dari pengamatan yang dilakukan pada saat proses pembelajaran dan dari hasil tes akhir kemampuan berpikir kreatif siswa.

\section{Proses Pembelajaran Inquiry pada Materi Teorema Pythagoras}

Proses pembelajaran yang menggunakan model pembelajaran inquiry pada Teorema Pythagoras berjalan dengan efektif yang membuat siswa dapat berpikir kreatif dalam setiap kegiatan yang dilakukan dan mampu memberikan solusi atau menciptakan sesuatu yang baru dalam menyelesaikan masalah. Hal tersebut terjadi karena pada proses pembelajaran di kelas eksperimen yang menggunakan model pembelajaran inquiry berjalan dengan cukup baik sesuai dengan langkah- 
langkah pembelajaran inquiry yaitu mengamati, merumuskan masalah, merumuskan atau memberikan dugaan sementara, mencari dan mengumpulkan data, menguji kebenaran jawaban dengan menggunakan data atau informasi yang telah diperoleh untuk menyelesaikan masalah dan memberikan kesimpulan. Pembelajaran inquiry memiliki strategi kerja kelompok yang melibatkan semua anggota kelompok untuk menyelesaikan tugas yang diberikan oleh guru, sehingga tidak ada siswa yang pasif dalam pembelajaran.

Pada pertemuan pertama, siswa diberikan tiga buah karton yang memiliki ukuran yang berbeda. Siswa diminta untuk menemukan Teorema Pythagoras dengan menggunakan karton yang telah diberikan di setiap kelompok dan mengikuti arahan yang diberikan guru. Tetapi arahan tersebut hanya sekedar instruksi kecil saja. Pada pertemuan pertama ini siswa terlihat masih kaku dan bingung dalam mengikuti arahan. Hal ini terjadi karena siswa memang belum terbiasa dengan model pembelajaran inquiry. Kekakuan siswa berkurang pada pertemuan kedua dan siswa mulai aktif terlibat dalam kegiatan pembelajaran. Bahkan pada pertemuan ketiga, siswa mulai terbiasa dan menyenangi pembelajaran yang menerapkan langkah-langkah pembelajaran inquiry. Pembelajaran dengan model pembelajaran inquiry telah memberikan kepercayaan diri kepada siswa bahwa mereka bisa mengembangkan kemampuan berpikir kreatif dalam pembelajaran matematika. Pada pertemuan keempat dan seterusnya, telah tampak bahwa siswa memahami tahapan-tahapan atau langkah-langkah model pembelajaran inquiry. Hal ini ditandai dengan tidak diperlukannya lagi arahan-arahan dan instruksi dari guru. Setiap siswa sudah dapat melaksanakan perannya masing-masing dengan baik.

Pembelajaran inquiry telah banyak dilaksanakan dalam upaya meningkatkan kemampuan siswa untuk memahami masalah yang dihadapi dan mampu menyelesaikan masalahnya secara mandiri dan bersikap layaknya seorang peneliti karena melakukan suatu aktivitas yang beragam yang melibatkan pengamatan, mengajukan pertanyaan, mencari atau menelaah sumber-sumber informasi atau data lainnya untuk menemukan kebenaran atas suatu permasalahan dan memberikan solusi yang tepat (Rianto, H., \& Santoso, R. H., 2014).

Tiap langkah-langkah pembelajaran memfasilitasi indikator-indikator kemampuan berpikir kreatif siswa sehingga kemampuan siswa dalam mengembangkan kemampuan berpikir kreatif dalam pembelajaran matematika dapat meningkat. Pada indikator kemampuan berpikir kreatif yang pertama yaitu fluency (kelancaran jawaban) bisa meningkat karena adanya langkah-langkah pembelajaran inquiry yang dilakukan secara berurutan dengan baik. Langkah-langkah pembelajaran tersebut adalah mengamati, merumuskan masalah, merumuskan hipotesis, mengumpulkan data, menguji hipotesis, dan kesimpulan. Dengan melakukan langkah-langkah tersebut akan mempermudah siswa dalam menyelesaikan permasalahan dengan benar dan lancar (lengkap). Selain mendukung indikator kemampuan berpikir kreatif yang pertama yaitu fluency (kelancaran jawaban), merumuskan hipotesis juga mendukung munculnya indikator kemampuan berpikir kreatif yang kedua yaitu flexibility (keragaman jawaban) karena pada saat merumuskan hipotesis, siswa memiliki cara-cara yang berbeda 
dalam menyelesaikan masalah yang ada. Siswa membuat jawaban sementara dari masalah tersebut dengan cara-cara yang mereka anggap benar dan tentunya akan muncul jawaban yang berbeda pula.

Pada saat mengumpulkan data dan menguji hipotesis tidak hanya mendukung indikator yang pertama yaitu fluency (kelancaran jawaban) tetapi juga mendukung indikator kemampuan berpikir kreatif yang ketiga yaitu originality (cara yang baru) karena dalam menguji hipotesis siswa mengumpulkan data dengan cara melakukan pencarian data sebanyak mungkin dan menyelesaikan masalah dengan cara yang berbeda bahkan dengan cara yang baru sesuai dengan pengetahuan yang mereka miliki atau jawaban yang unik dan khas yang ada pada diri siswa. Dengan melakukan langkah-langkah pembelajaran inquiry tersebut secara terus-menerus akan membiasakan siswa melakukan proses tersebut dalam pembelajaran dan dalam menyelesaikan masalah sehingga mempermudah siswa dalam menyelesaikan masalah atau persoalan yang diberikan dengan benar. Pernyataan tersebut sesuai dengan teori yang mengatakan bahwa kebiasaan belajar merupakan perilaku atau sikap yang dilakukan secara berulang-ulang dan tertanam dalam waktu yang relatif lama sehingga menjadi ciri khas dalam aktivitas belajar. Kebiasaan belajar akan mempengaruhi belajar itu sendiri yang bertujuan untuk mendapatkan pengetahuan, sikap, kecakapan, dan keterampilan siswa dalam mengerjakan tugas yang diberikan oleh guru. Dengan kata lain, kebiasaan belajar dapat mempengaruhi prestasi belajar siswa (Siagian, R. E. F., 2012).

\section{Efektivitas Model Pembelajaran Inquiry terhadap Kemampuan berpikir kreatif Belajar Matematika Siswa}

Setelah dilakukan proses pembelajaran dan dilakukan tes kemampuan berpikir kreatif siswa dalam pembelajaran matematika pada kelas eksperimen dan kelas kontrol, diperoleh data tentang kemampuan berpikir kreatif belajar matematika yang menggunakan model pembelajaran inquiry dengan model pembelajaran biasa yang dideskripsikan data hasil tes kemampuan berpikir kreatif belajar matematika berikut ini.

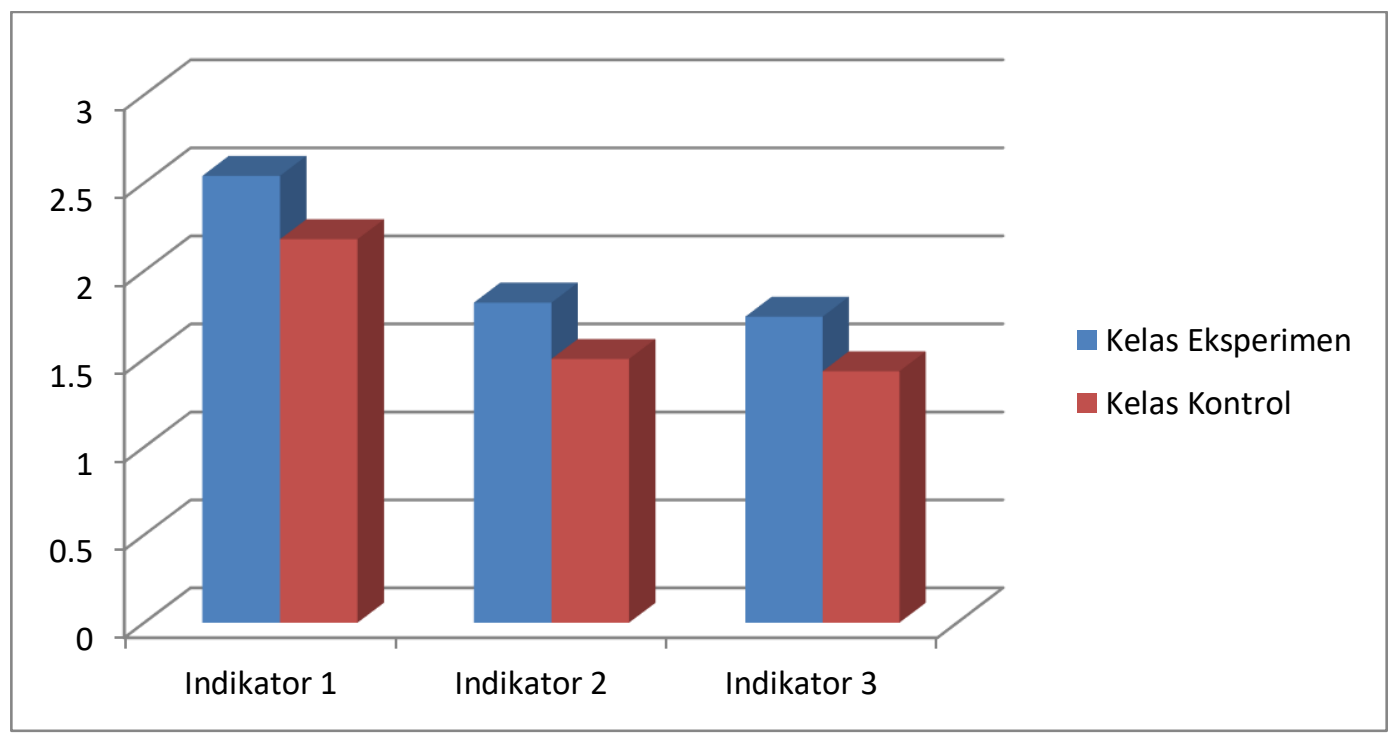

Gambar 1. Nilai Rata-Rata Hasil Postest Setiap Indikator Kemampuan Berpikir Kreatif 
(indikator 1: fluency, indikator 2: flexibility, indikator 3: originality)

Dari diagram tersebut terlihat adanya perbedaan nilai rata-rata siswa di setiap indikator. Pada indikator 1 nilai rata-rata siswa di kelas eksperimen adalah 2,54 sedangkan di kelas kontrol 2,18. Pada indikator 2 nilai rata-rata siswa di kelas eksperimen adalah 1,82 sedangkan di kelas kontrol adalah 1,5. Pada indikator 3 nilai rata-rata siswa di kelas eksperimen adalah 1,74 sedangkan di kelas kontrol adalah 1,43. Dari setiap indikator kemampuan berpikir kreatif menunjukkan bahwa nilai rata-rata kelas eksperimen lebih tinggi dibandingkan dengan nilai rata-rata kelas kontrol.

\section{Tabel 3.}

Rata-rata Kemampuan Kemampuan Berpikir Kreatif Siswa Kelas Eksperimen dan Kelas Kontrol

\begin{tabular}{ccc}
\hline & Rata-rata Skor (Eksperimen) & Rata-rata Skor (Kontrol) \\
\hline$X$ & 9,22 & 8,04 \\
\hline$S$ & 1,41 & 1,18 \\
\hline$S^{2}$ & 2,00 & 1,40 \\
\hline
\end{tabular}

Berdasarkan data di atas, diketahui bahwa perolehan rata-rata skor kemampuan berpikir kreatif siswa dalam pembelajaran matematika pada kelas yang menggunakan model pembelajaran inquiry lebih tinggi daripada kelas yang menggunakan model pembelajaran biasa. Model pembelajaran inquiry merupakan suatu model pembelajaran yang membuat siswa terlibat secara aktif dalam proses pembelajaran. Pembelajaran inquiry memiliki strategi kerja kelompok yang melibatkan semua anggota kelompok untuk menyelesaikan tugas yang diberikan oleh guru, sehingga tidak ada siswa yang pasif dalam pembelajaran. Siswa juga dilatih untuk berani mengemukakan pendapat dan berdiskusi dengan anggota kelompok dalam mencari, menyelidiki dan menciptakan cara-cara yang berbeda dalam menyelesaikan masalah atau tugas yang diberikan oleh guru sehingga setiap permasalahan matematika bisa diselesaikan dengan lebih mudah.

Pada pembelajaran konvensional, dalam proses pembelajarannya kurang melibatkan siswa secara aktif. Siswa hanya mendengarkan dan mencatat apa yang dijelaskan oleh guru sehingga siswa akan mudah jenuh. Pada proses pembelajarannya siswa tidak dituntut untuk menemukan sendiri permasalahannya dan tidak dituntut untuk memiliki kemampuan berpikir kreatif dalam memberikan atau menciptakan cara-cara yang berbeda dalam menyelesaikan masalah. Setelah diketahui bahwa adanya perbedaan antara kedua model pembelajaran, selanjutnya dilakukan analisis data dengan terlebih dahulu melakukan uji normalitas menggunakan uji liliefors yang hasilnya disajikan pada tabel 4 berikut.

\section{Tabel 4.}

Uji Normalitas

\begin{tabular}{ccc}
\hline & Kelas Eksperimen & Kelas Kontrol \\
\hline $\mathrm{L}_{0}$ & 0,0639 & 0,1742 \\
\hline $\mathrm{L}_{\mathrm{t}}$ & 0,1832 & 0,1832 \\
\hline
\end{tabular}


Dari tabel 4 di atas diperoleh hasil $\mathrm{L}_{0}<\mathrm{L}_{\mathrm{t}}$ yang berarti bahwa kedua kelas berdistribusi normal. Selanjutnya melakukan uji homogenitas varians menggunakan uji bartlett dengan kriteria pengujian $F_{\text {hitung }}<F_{\text {tabel }}$. Dari pengujian tersebut diperoleh hasil $F_{\text {hitung }}=1,4222$ dan $F_{\text {tabel }}=2,075$. Setelah itu, dilakukan uji hipotesis dengan menggunakan uji-t untuk mengetahui efektivitas atau pengaruh dari model pembelajaran inquiry terhadap kemampuan berpikir kreatif siswa dengan kriteria pengujian adalah $\mathrm{H}_{0}$ ditolak jika $t$-hitung $>t$-tabel. Hipotesis yang diuji adalah sebagai berikut:

$\mathrm{H}_{0}: \mu_{1}=\mu_{2}$ (Tidak terdapat pengaruh model pembelajaran inquiry terhadap kemampuan berpikir kreatif siswa).

$\mathrm{H}_{1}: \mu_{1} \neq \mu_{2}$ ( Terdapat pengaruh model pembelajaran inquiry terhadap kemampuan berpikir kreatif siswa).

Hasil perhitungan uji-t disajikan dalam tabel 5 di bawah ini.

\section{Tabel 5.}

Uji Hipotesis

\begin{tabular}{ccc}
\hline$t$-hitung & $t$-tabel & Kriteria \\
\hline 3,0048 & 2,0021 & $\mathrm{H}_{0}$ ditolak \\
\hline
\end{tabular}

Berdasarkan tabel 5 diperoleh hasil bahwa nilai $t$-hitung $>t$-tabel yang berarti $\mathrm{H}_{0}$ ditolak. Hal ini menunjukkan bahwa model pembelajaran inquiry berpengaruh terhadap kemampuan berpikir kreatif siswa. Penggunaan model pembelajaran yang tepat akan membuat proses pembelajaran berjalan dengan baik yang bertujuan untuk memecahkan masalah yang timbul dalam proses pembelajaran dan mengakibatkan adanya peningkatan keberhasilan belajar dalam bentuk kemampuan berpikir kreatif siswa. Hal ini sesuai dengan hasil penelitian yang telah dilakukan peneliti sebelumnya menunjukkan bahwa kemampuan berpikir siswa setelah diberikan treatment dengan pembelajaran open ended mulai mengalami peningkatan (Maryani, N., Marlina, N., \& Amelia, R. 2019).

Model pembelajaran inquiry bisa dijadikan model pembelajaran yang dapat meningkatkan kemampuan berpikir kreatif siswa dalam pembelajaran matematika dikarenakan model pembelajaran inquiry dapat melatih siswa untuk berpikir atau bernalar dalam berusaha memberikan kebenaran jawaban dari suatu permasalahan yang ada dengan bentuk yang berbeda bahkan dalam bentuk yang baru secara sistematis. Artinya model pembelajaran inquiry berpengaruh atau memiliki efektivitas (pencapaian) terhadap kemampuan berpikir kreatif siswa dalam pembelajaran matematika.

\section{KESIMPULAN}

Berdasarkan hasil penelitian dan pengujian hipotesis yang telah dilakukan maka dapat disimpulkan bahwa proses pembelajaran inquiry berjalan secara efektif yang dapat membuat siswa berperan aktif dan bekerja sendiri dalam mencari informasi atau pemecahan masalah selama proses pembelajaran berlangsung serta dapat menemukan ide-ide dan pemikiran yang baru sehingga dapat meningkatkan kemampuan berpikir kreatif siswa dalam pembelajaran matematika pada materi 
Teorema Pythagoras serta terdapat efektivitas atau keberhasilan model pembelajaran inquiry terhadap kemampuan berpikir kreatif siswa dalam pembelajaran matematika pada materi Teorema Pythagoras.

\section{DAFTAR PUSTAKA}

Desi, N., Gembong, S., \& Andari, T. (2013). Proses Berpikir Kreatif Siswa SMP yang Mengikuti Bimbingan Belajar dalam Menyelesaikan Soal-Soal Ujian Nasional. Jurnal Ilmiah Pendidikan Matematika, 1 (2), 1-15.

Fadilah, A. (2016). Pengaruh Pembelajaran Problem Solving terhadap Kemampuan Berpikir Kreatif Matematis Siswa. Jurnal Pendidikan Matematika dan Matematika, 2 (1), 1-8.

Fathurrohman, M. (2015). Paradigma Pembelajaran Kurikulum 2013. Yogyakarta: Kalimedia.

Khomsiatun, S., \& Retnawati, H. (2015). Pengembangan Perangkat Pembelajaran dengan Penemuan Terbimbing untuk Meningkatkan Kemampuan Pemecahan Masalah. Jurnal Riset Pendidikan Matematika, 2 (1), 92-106.

Lestari, K. E., \& Yudhanegara, M. R. (2015). Penelitian Pendidikan Matematika. Bandung: PT. Refika Aditama.

Majid, A. (2014). Pembelajaran Tematik Terpadu. Bandung: Rosdakarya.

Maryani, N., Marlina, N., \& Amelia, R. (2019). Upaya Meningkatkan Kemampuan Berpikir Kreatif Siswa Melalui Pendekatan Open Ended Materi Trigonometri. Jurnal Cendikia:Jurnal Pendidikan Matematika, 3 (1), 21-27.

Marliani, N. (2015). Peningkatan Kemampuan Berpikir Kreatif Matematis Siswa Melalui Model Pembelajaran Missouri Mathematics Project (MMP). Jurnal Formatif, 5 (1), 14-25.

Mashuri, I. (2012). Pengaruh Pembelajaran Berbasis Masalah dan Inquiry Ditinjau dari Kemandirian Belajar Siswa Kelas X SMA Negeri Kabupaten Blora. JMEE, 2 (1), 19-35.

Mufidah, L., Effendi D., \& Purwanti, T. T. (2013). Penerapan Model Pembelajaran Kooperatif Tipe TPS untuk Meningkatkan Aktivitas Belajar Siswa pada Pokok Bahasan Matriks. Jurnal Pendidikan Matematika STKIP PGRI Sidoarjo, 1 (1).

Putra, A., Syarifuddin, H., \& Zulfah. (2018). Validitas Lembar Kerja Peserta Didik Berbasis Penemuan Terbimbing dalam Upaya Meningkatkan Pemahaman Konsep dan Kemampuan Penalaran Matematis. Jurnal Riset Pendidikan Matematika, 1 (2), 56-62.

Siagian, R. E. F. (2012). Pengaruh Minat dan Kebiasaan Belajar Siswa Terhadap Prestasi Belajar Matematika. Jurnal Formatif, 2 (2), 122-131.

Sugiyono. (2014). Metode Penelitian Kombinasi. Bandung: CV ALFABETA.

Suripah, S., \& Sthephani, A. (2017). Kemampuan Berpikir Kreatif Matematis Mahasiswa dalam Menyelesaikan Akar Pangkat Persamaan Kompleks Berdasarkan Tingkat Kemampuan Akademik. Jurnal Pendidikan Matematika, 12 (2), 149-160.

Widiastuti, \& Santoso, R. H. (2014). Pengaruh Metode Inkuiri terhadap Ketercapaian Kompetensi Dasar, Rasa Ingin Tahu, dan Kemampuan Penalaran Matematis. Jurnal Pendidikan Matematika, 9 (2), 196-204. 
Wulansari, T., Putra, A., Rusliah, N., \& Habibi, M. (2019). Pengaruh Model Pembelajaran Berbasis Masalah pada Materi Statistika terhadap Kemampuan Penalaran Statistik Siswa. AKSIOMA: Jurnal Matematika dan Pendidikan Matematika, 10(1), 35-47.

Yumiati, \& Noviyanti, M. (2017). Analisys of Mathemaqtic Representation Ability of Junior High School Students in The Implementation of Guided Inquiry Learning. Journal of Mathematics Education, 6 (2), 137-148. doi: 10.22460/infinity.v6i2.p. 